Review Jurnal

\title{
MEMAHAMI KEBIJAKAN LUAR NEGERI KANADA DIRATIFIKASI PERJANJIAN KOMPREHENSIF DAN PROSES TRANS-PASIFIK KEMITRAAN (CPTPP) TAHUN 2018
}

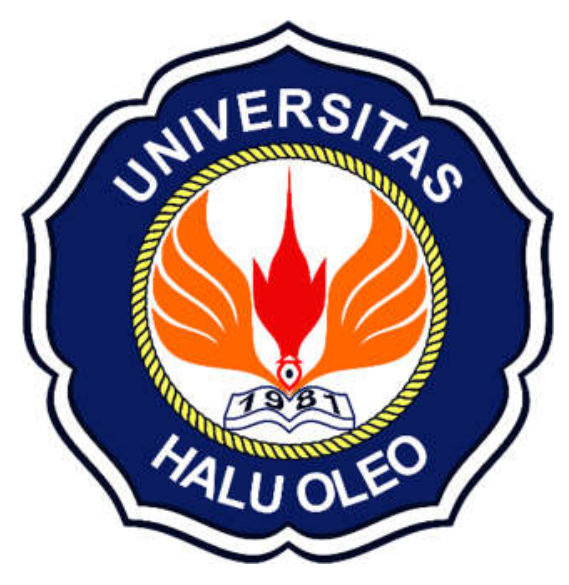

\author{
$\frac{\text { SITTI KALSUM }}{\text { NIM: C1A415116 }}$
}

JURUSAN ADM.NEGARA KOSENTRASI HUBUNGAN INTERNASIONAL FAKULTAS ILMU SOSIAL DAN POLITIK UNIVERSITAS HALU OLEO 
Permasalahan yang dibahas dalam penelitian ini adalah suatu perjanjian perdagangan Bebas di kawasan Asia-Pacific yaitu Comprehensive Agreement For TransPacific Partnership (CPTPP). CPTPP merupakan sebuah perjanjian sebuah perjanjian perdagangan bebas Multilateral yang sebelumnya dikenal sebagai Trans-Pacific Partnership (TPP). Mengganti perjanjian TPP dimana AS telah menarik diri dari keanggotaan, CPTPP merupakan langkah signifikan menuju hubungan perdagangan dan investasi yang lebih dekat dikawasan Asia-Pasifik dan menetapkan standar baru yang tinggi untuk perdagangan regional. Pada awal tahun 2017 ,kestabilan peran perjanjian kemitraan ini mulai diragukan karena AS meninggalkan keanggotaannya karena muncul keraguan Ameri Serikat sebagai penggerak utama di Liberalisasi perdagangan global Negara-negara di kawasan Asia Pasifik di pimpin oleh Presiden Donald Trump kini mulai menyusun kebijakan baru dimana kemitraan berbasis multilateral dengan Negara lain akan sangat sulit direalisasikan di banding dengan kerjasama bilateral. Proteksionisme oleh AS. telah secara signifikan mengurangi persentase keuntungan dari Negara anggota. Amerika Serikat memiliki kekuatan dalam pembangunan pembukaan pasar besar berdasarkan sector ekonomi. Perjanjian kemitraan TPP member ruang besar berupa akases perdagangan Negara berkembanng ke pasar Amerika Serikat, Jepang dan Australia. Kepercayaan internasional terhadapa efektivitas TPP semakin memburuk karena kritik dan akademi dan ekonomi doestik di berbagai Negara. Dan juga setelah keanggotaan Amerika Serikat mengundurkandiri permanen sehingga menjadi tidak stabil persoalan praktik neoliberal yang memposisikan investor dari korporasi besar diatas kepentingan masyarakat dan Negara. Pembentukan kembali anggota Juni-oktober 2018 enam Negara meratifikasikan perjanjian CPTPP, termaksut kanada yang mejadi negara kelima yang meratifikasi perjanjian ini. Kebijakan kanada dalam meratifikasi CPTTP tidak terlepas dari kepentingan nasional. 12 negara yang penandatangani TPP asli yaitu Australia,

Brunai Darunei,Kanada, Chili, Jepang, Malaysia, Meksiko, Selandia Baru, Peru, Singapura, Amerika Serikat dan Vietnam. TPP adalah kesepakatan yang bertujuan umtuk meliberalisasi perdagangan barang, jasa dan investasi serta untuk mengatasi perdagangan masalah yang muncul abad ke-21 seperti hambatan non-tarif, transparansi, dll. TransPacific Partneship (TPP) juga adalah perjanjian kerjasama yang dimulai dengan perjanjian khusus. Perjanjian perdagangan yang disebut kemitraan ekonomi strategis trans-pasifik (TPSEPS).

Tujuan dari penelitian ini yaitu menganalisis kepentingan ekonomi kanada untuk membuat kebijakan diratifikasi CPTPP pada 2018. Politik luar negeri dapat dipahami ebagai cara mengartikulasikan dan memperjuangkan kepentingan nasional, ini merupakan kesepakatan untuk kanada meningkatkan akses kepasar Asia Pasifik yang tumbuh cepat dan mendaptkan keuntungan dari penghapusan beberapa tarif antar perjanjian mitra. Akses akan memungkinkan kanada menjadi satu-satunya Negara G7 dengan akses perdagangan Preferensial ke Amerika Serikat, ke uni eropa, dan pasar Asia pasifik. Pemerintah kanada mengharapkan beberapa sector ekonomi mendapatkan keuntungan dari CPTPP. Oleh karena itu, perjanjian CPTPP yang diratifikasi, kanada akan mendapatkan keuntungan dari pasar liberalisasi melalui penghapudan tarif.

Metode yang digunakan dalam penelitian ini yaitu deskriptif dengan pendekatan kualitatif. penelitian kualitatif sebagai penelitian yang menghasilkan data deskriptif berupa tulisan atau kata-kata lisan dari orang-orang dan perilaku yang dapat diamati. Teknik pengumpulan dilakukan out menggunakan dua metode: pertama, wawancara melalui email dilakukan ke KJRI Jendral di Toronto Kanada, kedua: Dokumentasi, dikumpulkan melalui 
koleksi dokumen pemerintah, buku, jurnal, hasil studi akademi, dan artikel media massa. Metode analisis data yang digunakan adalah analiis metode interaktif yaitu menggunakan pengumpulan data, reduksi data, penyajian data, dan penarikan kesimpulan. Penelituan fokusnnya adalah kepentingan Ekonomi Kanada dalam meratifikasi komprekensif dan Progressive Agreement for the Prans-Pacific Partnership.

Kesimpulan dari penelitian ini yaitu perjanjian komperehensif dan progresif untuk kemitraan Trans-Pasifik (CPTPP)menawarkan insentif ekonomi untuk Negara-negara yang menandatangani perjanjian. Perjanjian dalam perjanjian ini kanada memiliki visi untuk meningkatkan pertumbuhan ekonomi Negara. Kebikebijakan kanada untuk meratifikasi perjanjian CPTPP karena kepentingan ekonomi. Pertama, kanada mendiviversifikasi pasar ekspornya untuk menurangi ketergantungannya yang signifikan pada pasar Amerika Serikat. Kedua, meningkatkan dan mempertahankan akses pasar dikawasan asia pasifik melalui penghapusan tarif di CPTPP persetujuan. Dan Ketiga, dari ekspansi pasar, kanada sekarang berdiri untuk mendapatkan keuntungan yang lebih kuat Asia Pasifik karena tidak harus berbagi keuntungan dari liberalisasi perdagangan dengan Amerika Serikat.

\section{References}

Alputra S, Faturachman, and Syastri Wulandari. 2019. "Understanding The Canadian Foreign Policy Ratified Comprehensive and Progressive Agreement for Trans-Pacific Partnership (CPTPP) in 2018." Journal Publicuho 2(4): 99. 